\title{
THE ELECTROPALATOGRAPHIC STUDY OF THE COARTICULATORY EFFECT OF VOWELS ON CORONAL STOPS IN PERSIAN
}

\author{
MARAL ASIAEE, MANDANA NOURBAKHSH, \\ SAEED RAHANDAZ
}

\begin{abstract}
Using electropalatographic (EPG) data, we study the coarticulatory effect of intervocalic contexts on the Persian coronal stops [t] and [d]. The EPG patterns demonstrate that $[\mathrm{d}]$ is produced in a more anterior place than $[\mathrm{t}]$, proving the former to be a dentialveolar consonant and the latter to be an alveolar one. The coarticulation index (CI) is calculated for each consonant flanked by the same vowels. The results obtained show that there is no significant difference between $[\mathrm{t}]$ and $[\mathrm{d}]$, in terms of coarticulation; however, based on the data we have, we can say that $[\mathrm{t}]$ is more resistant to coarticulatory effect than [d]. This result is in agreement with previous investigations which propose that laminals show stronger coarticulation resistance than apicals.
\end{abstract}

Key words: coarticulatory effect, coarticulation index, electropalatography, coronal stops, Persian

\section{Introduction}

Phoneticians and phonologists use place of articulation as one of the most important parameters when they describe segments. The phonetic representation of a phoneme is not always the same and it may vary according to the adjacent segments or its position in the syllable. This mostly occurs because of the overlapping gestures of the two neighboring segments. The change that occurs in articulation and acoustic signal of any segment due to its adjacent segments is called coarticulation; however, not all segments allow the same degree of coarticulation. Some are more resistant. Bladon and Al-Bamerni (1976) the first scholars who originally proposed Coarticulatory Resistance (CR) - postulated that a numerical $C R$ value can be designated to segments and their extrinsic allophones and this $\mathrm{CR}$ value can be used in the speech production mechanism to plan the coarticulatory directionality and magnitude for articulators.

Using their ears, linguists can detect some coarticulations which have traditionally been called allophones; but, with quantitative instrumental investigation, they can detect more detailed and meticulous variations (Kühnert and Nolan, 1999: 7). EPG is one of the 
instruments that can be used to assess whether the place of articulation of a phoneme has changed due to the coarticulatory effect.

EPG is a technique which depicts the contact between the tongue and the hard palate. The technique was first used by Grützner (1879) and since then it has gained popularity amongst phoneticians and speech therapists. In EPG, an artificial palate with 62 electrodes embedded on its lingual surface specially made for each individual is put against the hard palate to record the tongue/ palate contact. These 62 electrodes are arranged in 8 rows, each of which has 8 electrodes except the first row. The schematic arrangement of electrodes with their corresponding places of articulation is shown in Figure 1.

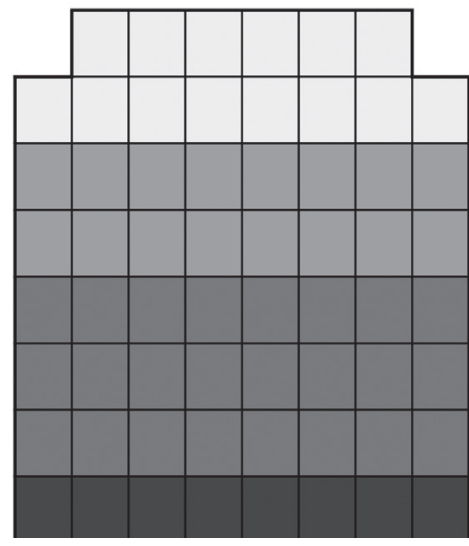

\author{
alveolar \\ post alveolar \\ palatal \\ velar
}

Figure 1. Schematic electrode arrangements with their corresponding places of articulation.

Numerous studies have investigated the coarticulatory effect using EPG. Some of the most extensive and comprehensive studies in this field were done by Recasens (1983, 1984a, 1984b, 1987, 1989). He compared Spanish and Catalan lingual consonants with different places and manners of articulation by means of EPG. He concluded that there was an inverse relationship between the coarticulatory effect and the degree of tongue dorsum elevation required for the consonants; that is, a progressive decrease in the degree of the tongue dorsum contact with the palate causes a progressive increase in the coarticulatory effect (Farnetani, 1989). His findings also indicated that those segments produced with an elevated tongue dorsum, were the ones most resistant to coarticulation and any contextual variation, but they were at the same time, the segments that caused the neighboring segments to vary the most.

Data from other languages also confirm Recasens' findings. Butcher and Weiher (1976) and Farnetani et al. (1985) studied German and Italian respectively and found [i] to be the most resistant vowel to the coarticulatory effect amongst other vowels; however, it was the most aggressive (or dominant) vowel in influencing the adjacent segments.

Farnetani (1989) studied coarticulation of VCV sequences for lingual consonants. She proposed a coarticulation index (CI) which was defined palatographically. Coarticulation index (CI) shows the contextual effects on a segment; that is, it shows variation both in the position of the contact and the amount of the contact (Farnetani, 1989: 113). She studied the effect of place of articulation and voicing on laterals and dentoalveolar stops in Italian. She also examined the coarticulatory effect on consonants flanked by stressed and unstressed 
vowels. The data obtained indicated that the coarticulation of tongue body varies inversely with the degree of tongue dorsum elevation. The CI decreased from alveolars to palatals. Within the alveolar category, CI decreased from laterals to voiced and voiceless stops.

Zharkova (2008) used EPG and ultrasound to investigate the lingual coarticulation in vowel- consonant sequences. She used an EPG measure and an ultrasound measure to compute the difference between /p, f, t, s, l, r, k/ in /a, i/ contexts in Scottish English. Results showed that labial consonants and /r/ were the most affected segments.

Chen, Chang \& Iskarous (2015) studied the speech of seven Taiwan Mandarin speakers. Their data consisted of CV syllables. Their results indicated that the high front vowel, [i], was more resistant to the coarticulatory effect than [a, u].

In this survey, we use EPG to compute the coarticulation index of Persian coronal stops and study the effect of different vowels on them. Persian belongs to the Indo-Iranian branch of Indo-European languages. It has six vowels /I, e, a, a, o, u/ and 23 consonants including eight plosives $/ \mathrm{p}-\mathrm{b}, \mathrm{t}-\mathrm{d}, \mathrm{c}-\mathrm{f}, \mathrm{G}, \mathrm{l} /$, eight fricatives $/ \mathrm{f}-\mathrm{v}, \mathrm{s}-\mathrm{z}, \int-\mathrm{z}, \mathrm{x}$, $\mathrm{h} /$, two affricates /t], $\mathrm{d} / \mathrm{l}$ and five sonorants / $\mathrm{m}, \mathrm{n}, \mathrm{j}, \mathrm{l}, \mathrm{r} /$. Previous impressionistic studies on Persian consider the place of articulation of coronal stops, namely [t] and [d], to be either dental, alveolar or dentialveolar (Mahootian, 1997; Nourbakhsh, 2009; Modarresi Ghavami, 2013 and 2018: 95; Bijankhan, 2018: 112). However, using EPG, Asiaee, Nourbakhsh and Skarnitzl (2018) showed that there was an asymmetry between the places of articulation of these speech sounds; they found [d] to be a dentialveolar stop, whereas [t] was an alveolar stop. Moddaresi Ghavami (2018) mentions the effect of the places of articulation of vowels on the production of their neighboring dorsal consonant - $[\mathrm{c}, \mathrm{f}]$; however, there have been no studies on the effect of vowels on coronal stops in Persian. This study aims to tackle this subject.

\section{Data and Method}

The speech was recorded at the Phonetic laboratory at Alzahra University, Tehran, Iran. The speaker was asked to wear the palate 30 minutes prior to the actual recording session to minimize unwanted possible effects of wearing an artificial palate. Using the EPG system by Rose Medical, we got the linguopalatal contact at the sampling rate of $100 \mathrm{~Hz}$, we also recorded the audio at the same time with the sampling rate of $16000 \mathrm{~Hz}$. We asked a female Persian speaker to read 12 disyllabic Persian words and pseudowords, three times. The words consist of coronal stops - $[\mathrm{t}]$ and $[\mathrm{d}]$ - located in intervocalic contexts where the two flanking vowels were the same. Persian has three front and three back vowels. Figure 2 shows the vowel space of Persian.

After the data was recorded, we used icSpeech Professional, a software which was provided by Rose Medical along with the EPG system to determine the onset and offset of the coronal stops in the intervocalic contexts.

To study the effect of vocalic coarticulation on the tongue-palate contact pattern, we needed a dataset in which coronal stops were flanked by the same vowels. The data that we collected fulfilled this need. To do so, coarticulation index was computed for [t] and [d] in each intervocalic context. Coarticulation index is calculated as the mean absolute difference between the percentages of contacted electrodes in all rows for each context. 
e

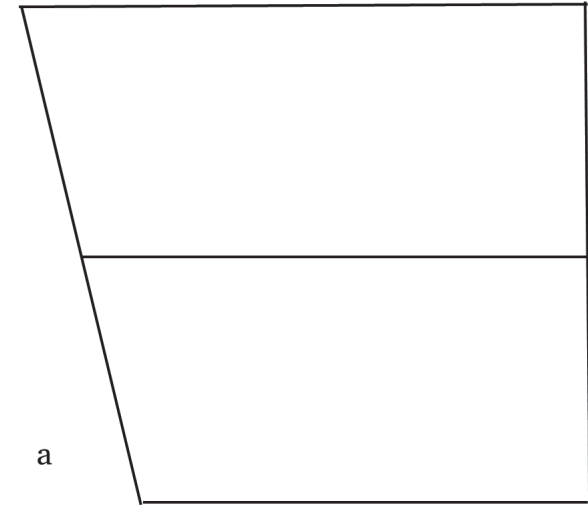

o

a

Figure 2. Persian vowel space (form Bijankhan, 2013: 136).

\section{Results and Discussion}

Figure 3 presents the EPG pattern for $[\mathrm{t}]$ and $[\mathrm{d}]$ as a mean across all repetitions and all intervocalic contexts.

The first row was consistently contacted in [d], which is expected from a dentialveolar segment. The EPG template and the CA index for the place of articulation of $[t]$ and [d] have shown that the former speech sound is an alveolar stop and the latter a dentialveolar one (for a full review see Asiaee et al., 2018).

[d]

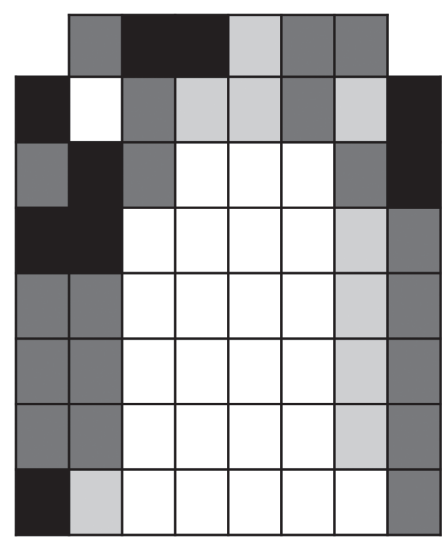

[t]

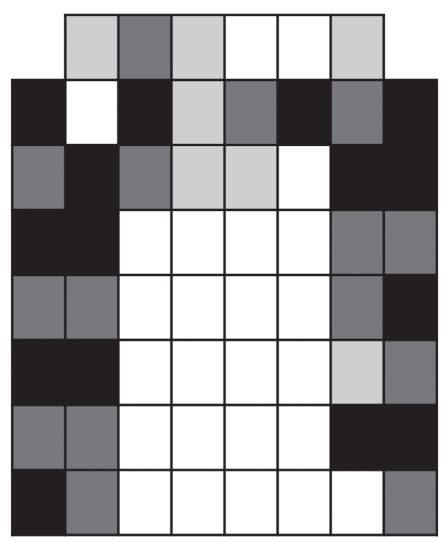

Figure 3. Mean of contacted electrodes across all three repetitions and all intervocalic contexts (black squares correspond to more than $90 \%$ electrodes being contacted, dark grey squares to 50-90 \%, light grey squares to $20-50 \%$ contacted electrodes). 

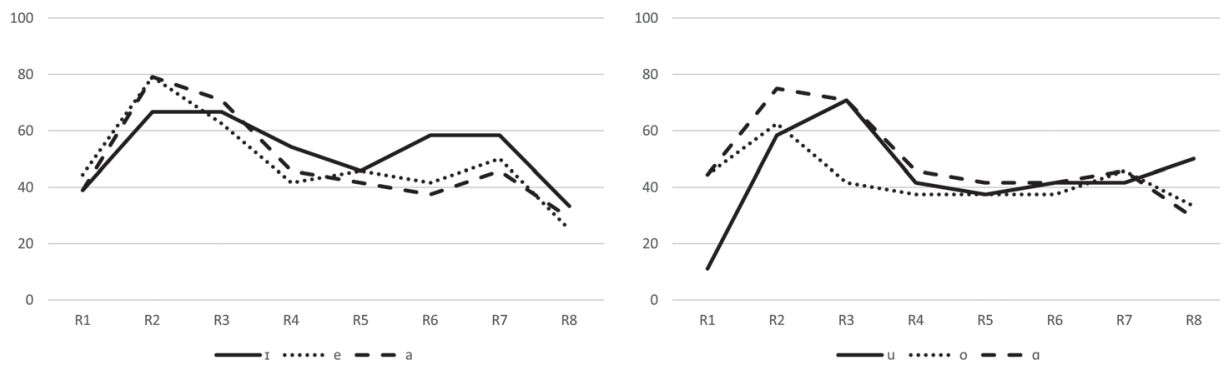

Figure 4. Percentages of contacted electrodes when [t] is flanked by Persian front vowels (left); Persian back vowels (right).

[d]

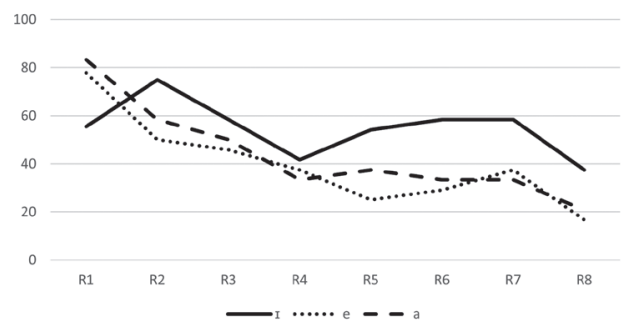

[d]

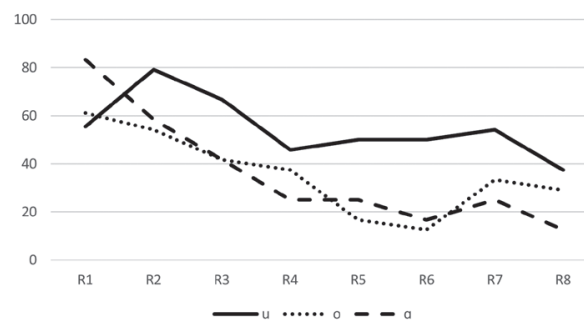

Figure 5. Percentages of contacted electrodes when $[\mathrm{d}]$ is flanked by Persian front vowels (left); Persian back vowels (right).

Figures 4 and 5 illustrate the mean percentage of contacted electrodes for $[t]$ and $[d]$ in different intervocalic contexts. Figure 4 shows the percentage of the contacted electrodes in each row where $[t]$ is flanked by front and back vowels. Since $[t]$ had the same percentage of contacted electrodes in both $[\mathrm{I}]$ and $[\mathrm{a}]$ contexts the absolute difference between these two intervocalic contexts was zero. In the second row of [t], the percentage of contacted electrodes was stronger than the first row in all three intervocalic contexts. As we moved backward, the number of contacted electrodes decreased gradually except for the [I] context- in which there was an increase in rows 5 to 7.

One possible reason for this pattern is the fact that [I] is a high vowel and as Recasens (1991: 179) mentions there is a decrease in the linguopalatal contacts in a progression from higher to lower front vowels all over the palate surface. In the context of back vowels, $[t]$ was produced in a posterior place. The number of contacted electrodes was the smallest in the context of $[\mathrm{u}]$ and it was more prominently drawn backward. It can be explained by the fact that according to Farnetani (1989) and Recasens (1987, 1989), the more elevated the tongue dorsum is, the more resistant the segment is to coarticulation, and the more aggressive that segment is in affecting the neighboring sounds. Hence, being a [+high] vowel, [u] affects the neighboring sounds more than a [-high] vowel. The absolute difference for [t] in the contexts of front and back vowels were $1.88,1.62,1.75,1,0.66,1.16,0.95$ and 1.41 respectively from row one to row eight. 
The coarticulation index for this speech sound which is calculated as the mean absolute difference was 1.30 .

Figure 5 illustrates the percentage of the contacted electrodes in each row where [d] is flanked by Persian front and back vowels. [d] was produced in a slightly more anterior position than $[t]$. The percentage of contacted electrodes were significantly higher in the first row for [d]. With the exception of the first row, the percentages of contacted electrodes in all rows was higher in the [I] context than the two other front vowels.

The high back vowel, [u], had almost the same pattern as [I]. [o] and [a] which are the mid and low back vowels respectively, affected [d] to be produced in a more posterior place, in comparison to [d] in the context of mid and low front vowels. The absolute differences for row one to row eight were 2.38, 2.08, 1.79, 1.29, 2.75. 3.33, 2.33 and 1.95. The coarticulation index for [d] was hence 2.24 .

Since there was a noticeable difference between the coarticulation index values of $[\mathrm{t}$ ] and $[\mathrm{d}]$, we examined the CI values of $[\mathrm{t}]$ and $[\mathrm{d}]$ in each intervocalic context separately

[t]

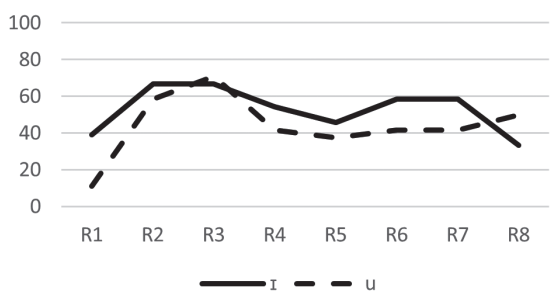

[t]

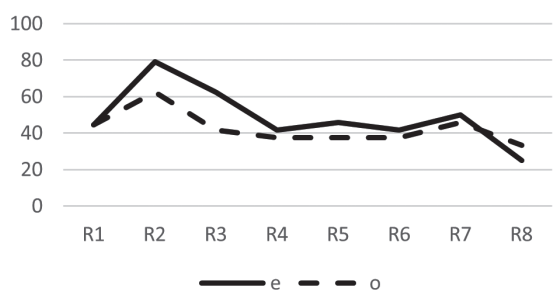

[t]

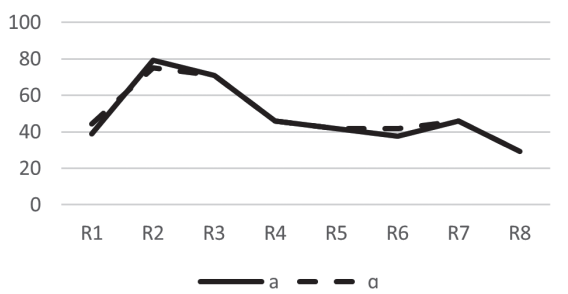

[d]

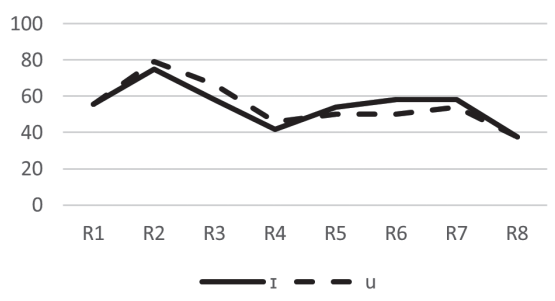

[d]

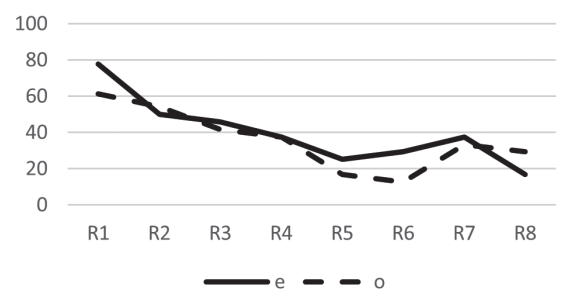

[d]

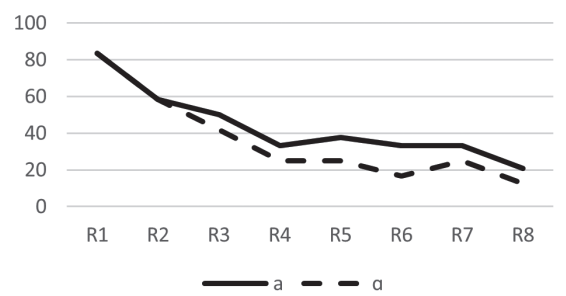

Figure 6. Percentages of contacted electrodes for $[\mathrm{t}]$ and $[\mathrm{d}]$ in each $[-$ back $] /[+$ back $]$ pair of Persian vowels. 
and conducted an independent sample t-test to compare the CI values for them. The Results obtained showed that there was no significant difference in the CI values for [t] $($ mean $=0.449722, \mathrm{SD}=0.0598)$ and $[\mathrm{d}]($ mean $=0.418650, \mathrm{SD}=0.1145) ; \mathrm{t}(10)=0.423$.

For a better understanding of how the [+back] feature has affected coronal stops in the intervocalic context, the charts for each [-back]/[+back] pair of Persian vowels are displayed in Figure 6 separately.

As it is obvious, in all the intervocalic contexts, the number of the contacted electrodes in [t] in the first row was less than the number of the contacted electrodes in [d] in the same row. When $[t]$ is flanked by [-back]/[+back] high vowels, the [+back] vowel drew it backward to a more posterior place. The same pattern can be seen for the mid [-back]/ [+back] vowels as well. However, for the low [-back]/[+back] vowels there was a subtle or no difference between the places of articulation of [t]. In these contexts, the absolute difference between R3-R5 and R7-R8 was zero. Contrary to [t], when [d] is flanked by [-back]/[+back] high vowels, not much noticeable difference can be recognized. In mid and low vowel contexts, [+back] vowels drew the place of articulation of [d] to a more posterior position than that of $[\mathrm{t}]$.

Recasens (1999) reported that voiced dental or alveolar stops are more affected by coarticulation than their voiceless counterparts. Since, in Persian, the distinction between [t] and $[\mathrm{d}]$ in intervocalic contexts is not realized by voicing, but by aspiration (Nourbakhsh, 2009), the difference between the degree of resistance in $[t]$ and [d] cannot be explained by voicing. This variation might be due to the fact that $[t]$ is a laminal sound, while [d] is an apical one. Bladon and Nolan (1977) studied the alveolar consonants in RP English. They found that laminal speech sounds were more resistant to coarticulation than the apical ones. They argue the reason is that it is the tip rather than the blade that has the more distance from the dorsum when it is active in vocalic gestures. Skarnitzl (2013) reported that $[t]$ being a voiceless laminal sound had stronger coarticulation resistance than $[\mathrm{d}]$ as an apical voiced sound.

\section{Conclusion}

The objective of this study was to determine if intervocalic contexts have an effect on the coarticulation of coronal stops in Persian. We first used electropalatography (EPG) to delineate the precise places of articulation of $[t]$ and $[d]$. We then analyzed our data by computing the coarticulation index proposed by Farnetani (1989). The overall CI value in all intervocalic contexts was 1.30 for [t] and 2.24 for [d]. Finally, an independent sample $\mathrm{t}$-test was conducted to compare the CI values in [t] and [d]. The results manifest that there is no significant difference between the degree of the coarticulatory effect in $[t]$ and $[d]$. However, by looking at the data and the $C I$ values of $[t]$ and $[d]$ in each vocalic context separately, we can say that $[t]$ shows a slightly stronger coarticulation resistance than [d], Of course the result is tentative since we only recorded and analyzed the speech of one speaker. This might be explained by the fact that $[t]$ is a laminal stop, while [d] is an apical one. 


\section{REFERENCES}

Asiaee, M., Nourbakhsh, M. \& Skarnitzl, R. (2018). Coronal stops in Persian: An electropalatographic study. In: M. Nourbakhsh, H. Asadi \& M. Asiaee (Eds.), Proceedings of First International Conference on Laboratory Phonetics and Phonology, 37-44. Tehran: Neveeseh Parsi Publications.

Bijankhan, M. (2013). Phonetic System of the Persian Language. Tehran: Samt.

Bijankhan, M. (2018). Phonology. In: A. Sedighi and P. Shabani- Jadidi (Eds.), The Oxford Handbook of Persian Linguistics, 111-141. Oxford: Oxford University Press.

Bladon, R. A. W. \& Al-Bamerni, A. (1976). Coarticulation resistance in English /1/. Journal of Phonetics, $4,137-150$.

Bladon, R. A. W. \& Nolan, F. (1977). A video-fluorographic investigation of tip and blade alveolars in English. Journal of Phonetics, 5, 185-193.

Butcher, A. \& Weiher, E. (1976). An electropalatographic investigation of coarticulation in VCV sequences. Journal of Phonetics, 15, 111-126.

Chen, W., Chang, Y., \& Iskarous, K. (2015). Vowel coarticulation: landmark statistics measure vowel aggression. Journal of the Acoustical Society of America, 138, 1221-1232.

Farnetani, E. (1989). V-C-V Lingual Coarticulation and its Spatiotemporal Domain. In: W. J., Hardcastle \& A. Marchal (Eds.), Proceedings of the NATO Advanced Study Institute on Speech Production and Speech Modelling, 93-130. Dordrecht: Kluwer Academic Publishers in cooperation with NATO Scientific Affairs Division.

Farnetani, E., Vagges, K. \& Magno-Caldognetto, E. (1985). Coarticulation in Italian /VtV/ Sequences: A Palatographic Study. Phonetica, 42(2-3), 78-99.

Grützner, P. (1879). Physiology of voice and speech. In Hermman's Handbook of Physiology (1 \& 2). (p.165204). Leipzig.

Kühnert, B. \& Nolan, F. (1999). The origin of coarticulation. In W. Hardcastle \& N. Hewlett (Eds.), Coarticulation: Theory, Data and Techniques (pp. 7-30). Cambridge: Cambridge University Press.

Mahootian, Sh. \& Gebhart, L. (1997). Persian (Descriptive Grammars). London: Taylor \& Francis Routledge.

Modarresi Ghavami, G. (2013). Phonetics: Scientific Study of Speech. Tehran: Samt.

Modarresi Ghavami, G. (2018). Phonetics. In: A. Sedighi and P. Shabani- Jadidi (Eds.), The Oxford Handbook of Persian Linguistics, 91-110. Oxford: Oxford University Press.

Nourbakhsh, M. (2009). Distinctive role of voice onset time (VOT) in standard Persian oral stops. $\mathrm{PhD}$ dissertation. University of Tehran.

Recasens, D. (1983). Timing and coarticulation for alveolo-palatals and sequences of alveolar [j] in Catalan. Haskins Laboratories Status Rep. Speech Res, 74/75, 97-112.

Recasens, D. (1984a). V-to-C coarticulation in Catalan VCV sequences: an articulatory and acoustical study. Journal of Phonetics, 12, 61-73.

Recasens, D. (1984b). Vowel-to-Vowel coarticulation in Catalan VCV sequences. Journal of acoustical Society of America, 76, 1624-1635.

Recasens, D. (1987). An acoustic analysis of V-to-C and V-to-V coarticulatory effects in Catalan and Spanish VCV sequences. Journal of Phonetics, 15, 299-312.

Recasens, D. (1989). Long range coarticulatory effects for tongue dorsum contact in VCVCV sequences. Speech Communication, 8(4), 293-307.

Recasens, D. (1991). An electropalatographic and acoustic study of consonant-to-vowel coarticulation. Journal of Phonetics, 19(2), 177-192.

Recasens, D. (1999). Lingual coarticulation. In W. Hardcastle \& N. Hewlett (Eds.), Coarticulation: Theory, Data and Techniques (pp. 80-104). Cambridge: Cambridge University Press.

Recasens, D. \& Espinosa, A. (2009). An articulatory investigation of lingual coarticulatory resistance and aggressiveness for consonants and vowels in Catalan. Journal of Acoustical Society of America, 125, $2288-2298$.

Skarnitzl, R. (2013). Asymmetry in the Czech alveolar stops: An EPG study. AUC Philologica 1/2014, Phonetica Pragensia XIII, 101-112. 
Zharkova, N. (2008). An EPG and Ultrasound Study of Lingual Coarticulation in Vowel-Consonant Sequences. In: R. Sock, S. Fuchs \& Y. Laprie (Eds.). Proceedings of the 8th International Seminar on Speech Production, 241-244. Strasbourg: INRIA.

\section{RESUMÉ}

Studie analyzuje artikulaci koronálních exploziv [t] a [d] v perštině pomocí elektropalatografie (EPG). Zaměřuje se především na koartikulační vliv sousedních vokálů na jejich realizaci. Vzorce EPG naznačují, že [d] je realizováno s anteriornějším postavením jazyka jako dentialveolární hláska, zatímco [t] je alveolární. Pro každý konsonant je stanoven koartikulační index (CI). Výsledky nenaznačují výraznější rozdíl mezi oběma hláskami z hlediska koartikulace, ale [t] vykazuje vyšší míru koartikulační rezistence vůči okolnímu vokalickému kontextu než [d]. To je v souladu s výzkumy, které poukazují na silnější koartikulační rezistenci u laminálních hlásek než u hlásek apikálních.

\section{Maral Asiaee and Mandana Nourbakhsh}

Department of Linguistics

Alzahra University, Tehran, Iran

E-mail:m.asiaee@alzahra.ac.ir

\section{Saeed Rahandaz}

Department of Linguistics

Bu-Ali Sina University, Hamedan, Iran 